\title{
Kerk en struktuur
}

\author{
AD Pont
}

\section{Inleidende opmerkings}

Die besluit van die Algemene Kerkvergadering van 1979 dat dié vergadering se ledetal beperk moet word ${ }^{1}$, het tot dusver weinig reaksie of bespreking in die Kerk uitgelok. Miskien hang dit saam met die feit dat oor die algemeen die hele saak van die organisatoriese struktuur van die kerk nie veel belangstelling geniet nie'. In 'n sekere $\sin$ is dit verstaanbaar, want die taak van die kerk, die volk van $\mathrm{God}^{3}$ of die liggaam van Christus is primêr om die getuie van Jesus Christus ${ }^{4}$ in die wêreld te wees. Die organisatoriese struktuur is van meet af ' $n$ middel tot ' $n$ doel en nié die doel self nie ${ }^{5}$, maar daarom nie onbelangrik nie. Die apostel Paulus stel immers dat daar ' $n$ vaste orde in die gemeente of volk van God moet wees ${ }^{6}$. Daardie orde is deel van die gehoorsaamheid van die geloof. Dit is ook nie toevallig dat in die reformatoriese $16 \mathrm{de}$ eeu die kerkorde as ' $n$ aanhangsel van die geloofsbelydenis voorkom nie?

Omdat die reformatoriese vadere die organisatoriese struktuur wel belangrik geag het, het hulle ' $n$ duidelike samehang van Skrif, belydenisskrif en kerklike orde na vore gebring. Die samehang word in die $18 \mathrm{de}$ en $19 \mathrm{de}$ eeu met die verrasionalisering van die Teologie grotendeels verbreek'. Dit is in daardie tyd dat Rud Sohm die stelling kan maak dat elke vorm van kerklike reg of van 'n vaste, organisatoriese struktuur in stryd is met die essensieel godsdienstige karakter van die kerk $^{10}$. Tog is dit duidelik dat die 18de-en 19de-eeuse skeiding van die sigbare (organisatoriese) kerk wat antiteties sou staan teenoor die onsigbare (geloofsgemeenskap) kerk in die lig van die kerkbegrip van die Nuwe Testament onhoudbaar is ${ }^{11}$. Die reformatoriese opvatting van die innerlike samehang wat daar moet wees tussen Skrifgegewens, die kerklike verstaan van die Skrif, soos dit primêr in die belydenisskrif gegee word, en die kerklike orde is op hierdie vlak 'n saak van wesenlike betekenis.

As oor die kerk en sy organisatoriese struktuur 'n paar opmerkings gemaak word, kan dit nie anders as dat dit vanuit dié gesigshoek gedoen word nie. Sodra dit gesê is, kom ook die vraag na die ius divinum èn wat daaronder verstaan moet word, na vore ${ }^{12}$. Laat dit dadelik gestel word dat dié vraag èn die beantwoording daarvan op sigself reeds ' $n$ lang uiteensetting moonlik maak ${ }^{13}$. Dit is egter nie binne die bestek van hierdie uiteensetting moontlik om indringend op hierdie vraag in te gaan nie. Tog is dit in die verband van die kerklike organisasie duidelik dat die ius divinum afgelees ward sowel 
uit die Skrif, wat God se wil en weg aan die mens openbaar ${ }^{14}$ as uit die lex Dei wat ook in die Skrif gegee word. Langs hierdie weg kom ook, veral in die Calvinistiese kring, die kerklike orde na vore en, histories gesproke, speel die Straatsburgse Hervormer, Martin Bucer, hierin ' $\mathrm{n}$ belangkrike rol $^{15}$. Uiteindelik is die werk van Johannes Calvyn van beslissende belang vir die strukturering van byvoorbeeld die Hervormde Kerk in Genève, Frankryk en Nederland ${ }^{\mathbf{1 6}}$.

Vanweë die beginselstandpunte wat die Calvinistiese kerke op grond van die Skrif inneem, word dit duidelik dat die orde van die kerk 'n gehoorsaamheidsorde is, dit wil sê gehoorsaamheid aan die verkondigde Woord ${ }^{\mathbf{1 7}}$ en aan Jesus Christus wat as die enigste Hoof en Heer van die kerk bely word ${ }^{18}$.

Die vraag kan natuurlik gestel word of daar, volgens die Skrif, dan net één werklik Goddelik-bepaalde kerklike organisasievorm kan wees $^{19}$. In hierdie verband is Calvyn se opmerking in sy Kommentaar op I Korintiërs 11:12 nogal belangrik. Hy stel dat die kerklike orde ontstaan vanweë die communi consensu van die lidmate wat in gehoorsaamheid aan die Woord optree. Dan stel hy:

"... ons weet dat elke kerk die vryheid het om vir homself 'n orde van regering (politiae formam) op te stel wat vir daardie kerk paslik en bruikbaar is omdat die Heer nie iets bepaalds voorgeskryf het nie."

So gebeur dit dat die verskillende Calvinistiese kerke nie identies kerklike strukture oprig nie. Die historiese situasie en in baie gevalle ook die verhouding met die owerheid èn die owerhede se bemoeienisse met die strukturering van die kerk, het meegebring dat daar tog duidelike verskille ontstaan het. Aan die ander kant is daar ook weer 'n merkwaardige ooreenkoms èn wisselwerking tussen die verskillende Calvinistiese kerkordes wat in Genève, Frankryk, Nederland, Skotland, Hongarye, die Paltz en ander plekke ontstaan het. Hoewel die Nederlandse kerkordenende tradisie vir òns van wesenlike belang is, bied dié ander tradisies belangrike vergelykende materiaal as die reformatoriese (=Calvinistiese) kerkreg nagegaan word. Hoewel dit onmoonlik is om in besonderhede dié saak te behandel, kan, wat die uitgangspunt betref, korkliks die volgende gestel word.

Omdat ons Calvinistiese vadere oortuig was van die noodsaaklikheid dat die kerklike organisasie en die regering van die kerk Skriftuurlik veranker moet wees, het hulle 'n direkte verband tussen die belydenisskrif en die kerklike orde gehandhaaf. Op dié manier, so kan mens sê, kry die kerklike orde byna'n konfessionele karakter. Dít was die uitvloeisel van die reformatoriese opvatting dat Jesus Christus die enige Hoof en Heer van sy kerk is wie se bestaan en 
lewe deur sy Gees èn Woord bepaal word. Wat die kerk ten opsigte van die kerklike organisasie èn regering kan èn wil sê, moet 'n verband hê met die Woord of die evangelie wat die kerk uitdra èn wat die kerk in aansyn roep. Tog is die kerklike orde as sodanig nooit beskou as deel van die belydenisskrif nie, maar as 'n uitvloeisel van die belydenis, want die kerklike organisasie móét, selfs wat die besonderhede betref, in die ekklesiologie, in die pura et sana doctrina wat die kerk (moet) bely, gewortel wees ${ }^{20}$.

As daar nou 'n oomblik na die hele aangeleentheid van kerk en struktuur of kerk en kerklike organisasie en orde gekyk word, kan die volgende gesigspunte na vore gebring word. Dit word gedoen vanuit die reformatoriese opvatting omdat die gesprek oor die kerklike orde binne dié raamwerk gehou moet word om dit, vir die praktyk, as 'n gehoorsaamheidsorde te behou.

\section{Die omskrywing van die kerk}

In die denke van Joh Calvyn is dit opvallend dat die kerk primêr as 'n pneumatiese organisme verstaan word ${ }^{21}$. Dit gebeur veral omdat Calvyn se denke sterk bepaal word deur die Pauliniese omskrywing dat die kerk, dit is die geroepe gelowiges, almal saam die liggaam vorm waarvan Jesus Christus die enige Hoof en Heer is ${ }^{22}$. Dieselfde standpunt kan ook in die Nederlandse Geloofsbelydenis en ander reformatoriese belydenisskrifte teruggevind word ${ }^{23}$. Die omskrywing van die kerklike organisasie binne die kader van die reformatoriese denke is die poging om hierdie pneumatiese organisme as 'n sigbare organisasie in die wêreld te struktureer op só 'n manier dat die pneumaties-dinamiese wesenskenmerk van die kerk as liggaam van Christus behoue bly. Daarom word daar ook soveel klem gelê op die feit dat Jesus Christus self sy kerk "die heilige vergadering van almal wat waarlik in Christus glo, wat almal hulle heil in Jesus Christus verwag en in sy bloed gewas is, geheilig en beseël deur die Heilige Gees" (NGB, art 27) regeer ${ }^{24}$.

Die sterk beklemtoning van die feit dat Jesus Christus sèlf sy kerk regeer, hang saam met die belydenis dat die Heilige Gees en die Woord van God dié $\mathrm{krag}$ is wat die uitverkore gelowiges bymekaarbring, beskerm en onderhou ${ }^{25}$. Die gemeenskaap van die gelowiges wat saam, korporatief dus, die Woord van God glo èn gehoorsaam is, om so in heiligheid toe te neem ${ }^{26}$, moet as 'n skeppingsdaad van die Heilige Gees bely word ${ }^{27}$. Die gelowiges self word nié tot 'n salige niks-doen verneder nie, maar word volledig opgeneem in die diens van God wat egter volkome dankbaarheidsdiens is waarop niemand mag roem nie ${ }^{23}$.

Die Heilige Gees wat die Vader en die Seun in die gemeente 
verteenwoordig en teenwoordig maak, werk ín die gemeente deur die Woord van God en van hieruit kry die gepredikte Woord wat deur die Gees gebruik word, sy sentrale posisie in die ruimte van die kerk (= die liggaam van Christus) ${ }^{29}$. Vanuit hierdie gesigspunt word ook die merktekens van die ware kerk omskryf as die suiwere of regte verkondiging van die Woord van God, die Skrifmatige bediening van die sakramente en dan as derde die heiliging, die handhawing van die tug en dissipline ofte wel die onderwerping in gehoorsaamheid aan die Woord van God ${ }^{30}$.

So word die liggaam van Christus of die koninkryk as heerskappy van God in die gemeente wat die kerk is, sigbaar. Die kerk van Christus is aanwesig in sover die Woord van God en die Heilige Gees gehoorsaam word. Die kerk is dus nie in die biskoppe of in die konsilies sigbaar nie, maar in die gemeenskaap van die geroepe heiliges ${ }^{31}$. Daardie gemeenskaap van geroepe heiliges regeer Jesus Christus as hoof van sy liggaam direk deur die Heilige Gees en die Woord van God en indirek of middellik deur die geroepe amp (Ef 4:11-12).

In die kerk is Jesus Christus eintlik die enigste gesagsdraer èn Hoof (Kol 1:18; Ef 5:23; Ef 1:22-23; Ef 4:15-16), maar Hy gebruik ook mense om in sy Naam en onder sy gesag, in gehoorsaamheid aan die Woord en gelei deur die Gees, om die gemeente van geroepe heiliges op te bou en toe te rus vir hulle dienswerk in die wêreld ${ }^{32}$. Die grense van die gesag van dié diensknegte (= ampte) is die Woord van God, en hulle' moet die kerk "ooreenkomstig die geestelike bestuurswyse wat ons Here ons in sy Woord geleer het", regeer ${ }^{33}$.

\section{Die kerklike struktuur}

Die opbou van die kerklike struktuur, orde of organisasie geskied dus, in die reformatoriese tyd, om die Christokrasie oor die gemeenskap van die geroepe heiliges tot uitdrukking te bring. Die Skriftuurlike vertrekpunte word in die reformatoriese tyd gewoonlik aangedui as Efesiërs 2:20-21; I Korinthiërs 12:27 en ook Efesiërs 4:12 en 16 .

Die grondliggende beginsels van die sigbare kerklike struktuur kan soos volg aangedui word:

1. Jesus Christus is die enige, gesaghebbende Hoof en Heer van die kerk. Die kerk is die geroepe heiliges, die volk van God wat in en deur die geloof en deur die werk van die Heilige Gees direk met Jesus Christus verbind is ${ }^{34}$.

Dit is duidelik dat God self bepaal wie die uitverkorenes, die ware lede van die liggaam van die kerk is. In die kerklike struktuur gaan dit vanselfsprekend om die sigbare kerk en daarom word op hierdie vlak duidelik gestel wat die voorwaardes vir 
lidmaatskap van die kerk (= plaaslike gemeente) is. Dit word egter as vanselfsprekend aanvaar dat die sigbare kerk, 'n corpus permixtum (Augustinus) is en dat lidmaatskap van die kerk, al staan so ' $n$ mens binne die verbond vanweë die doop, nie terselfdertyd vanselfsprekend beteken dat so ' $n$ mens ' $n$ uitverkorene is nie.

2. Die liggaam van Christus (= die kerk) se lewe en organisasie word bepaal deur die aanwysings en opdragte van die Heilige Skrif, want die Skrif trek die grondpatroon van die lewe van die gelowiges èn dit is die norm van geloof en lewe.

3. Die sigbare verskyningsvorm van die kerk (= die volk van God) op aarde is die plaaslike gemeente en aan dié gemeenskap van die geroepe gelowiges skenk Christus alles wat die gemeente nodig het om voort te bestaan en sy roeping na te kom.

4. Die kerk word indirek deur Christus self geregeer wanneer $\mathrm{Hy}$ mense roep tot die diens van Woordverkondiging, regering en barmhartigheidsdiens. Hierdie dienswerk wat ingestel is, gesag van Christus self ontvang en deur die Gees van God gedra word, bevorder die eenheid in die geloof, die gehoorsaamheid aan die Woord en die uitvoering van hulle roeping deur die gelowiges. Die gesag in die kerk lê primêr by Jesus Christus wat die enigste gesagsdraer in sy kerk is. Die amp het egter óók gesag vir sover die ampsdraer in gehoorsaamheid aan die Woord binne die grense van die Woord bly.

5. Die ampte wat gesag ontvang het (vanweë hulle roeping en bevestiging in die amp), verrig hulle dienswerk nooit alleen of individueel nie. Om die hiërargie-vorming in die amp teen te gaan, kom die amp in die uitvoering van sy dienswerk in ' $n$ vergadering byeen. Dit wil nie sê dat die vergadering 'n eie gesag het nie, maar slegs dat die gesamentlike gesag van die ampsdraers 'n vergadering se uitspraak gesaghebbend maak.

Die amp wat die kerk (gemeente) regeer, moet sy dienswerk so verrig dat die direkte verhouding en verbondenheid van Jesus Christus met sy liggaam, met die gelowiges dus, nie versteur word nie.

6. Die meerdere vergaderings in die liggaam van die kerk is nooit hoër vergaderings as die basies-verantwoordelike regeervergadering, die kerkraad, nie. Dit is slegs meerdere vergaderings omdat daar ' $n$ meerdere verteenwoordiging van die (gesaghebbende) amp is en omdat dié vergaderings oor aangeleenthede moet handel wat 'n wyer trefkrag het as dié soort sake waaroor' $n$ kerkraad kan handel - byvoorbeeld die leer, die ordening van die kerk en dies meer. Om 'n hiërargie-vorming te vermy, word verder ' $n$ rotasie-beginsel ten opsigte van afgevaardigdes ingestel en om groot en lomp vergaderings te vermy, word 'n trapsgewyse 
afvaardiging na die verskillende meerdere vergaderings ingestel. Terselfdertyd behou elke ampsdraer 'n spreekreg op die meerdere vergaderings, hoewel slegs die afgevaardigde ampsdraer stemreg het.

7. In die reformatoriese kerkordes kom daar nie kontinuerings- of uitvoerende kommissies van die verskillende meerdere vergaderings voor nie, aangesien dié meerdere vergaderings as "organe van bystand" ten opsigte van die kerkraad funksioneer. Die kerkraad is die enigste staande regeervergadering en sy lede funksioneer as die uitvoerders van die besluite van die meerdere vergaderings. Die ampsdraers sèlf is dus die uitvoerders van die besluite wat hulle saam, in die vergadering, in gehoorsaamheid aan die Woord, onder leiding van die Heilige Gees en met in agneming van die kerklike orde, geneem het.

8. Verder word die eenheid-met-die-kerk beklemtoon - dit wil sê die uitleef van die gemeenskap van die gelowiges (verbond!) op die breër as net die plaaslike vlak. Dié saak kom veral sterk na vore in die Franse kerk waar, anders as in Genèva, rekening gehou word met 'n landswye "liggaam van die kerk". Hier moet opgepas word dat nie, in navolging van die 19de-eeuse Doleansiekerkreg, die gemeente (kerk) tot 'n outonome liggaam verklaar word nie. Dit is ook terloops, interessant dat die gemeentes nêrens in Frankryk, die Suidelike Nederlande in die periode tot 1565 of daarna in die kerkordelike ontwikkeling ná die Konvent van Wezel ' $n$ kerkverband skep nie. Dit is ook, gesien die reformatoriese kerkreg, nie moontlik om 'n kerkverband te stig of te skep nie, want die kerk, die volk van God is 'n eenheid in geloof en diens. Dit hoef slegs organisatories uitgedruk te word. Miskien kan net daarop gewys word dat ons, in ons kerkordenende denke, in reaksie teen die Doleansiekerkreg èn onder invloed van die verenigingsreg weer te veel die geheel oorbeklemtoon en só die selfstandigheid en verantwoordelikheid van gemeente en kerkraad tot ' $n$ absolute minimum, dikwels selfs onmondigheid reduseer. Dit is baíe beslis in stryd met die ekklesiologie van ons belydenisskrifte.

9. Ten slotte handel die reformatoriese kerkordes direk of indirek, oor die verhouding tot die burgerlike owerheid, wat 'n saak is wat in die belydenisskrifte genoem word. Daaroor word hier nie verder gehandel nie.

As dit gestel word, is dit duidelik dat die presbiteriaal-sinodale kerklike ordening veral teruggryp op die gegewens wat in die Pauliniese Teologie in die Nuwe Testament gevind word. Dié kerklike struktuur is een van die organisatoriese strukture wat vanuit die Nuwe Testament gestel kan word. Soos Esser dit stel ${ }^{35}$ : 
"In the Reformation period, and especially when it was a case of completely rebuilding the church afresh, the Reformed Church decided in favour of the early Pauline form of church order, not simply because of historically conditioned alienation from the hierarchally ordered Church but also not exclusively either. Out of the local form of the presbyterially structured congregational leadership the presbyterial, synodal order was developed for the regional, national and supranational ecumenical levels."

Die presbiteriaal-sinodale kerkordelike struktuur het 'n duidelike Skriftuurlike basis en is ook, dansy die geniale insig van Joh Calvyn, 'n struktuur wat inderdaad uitdrukking wil gee aan die feit dat Jesus Christus self sy kerk regeer, lei en bewaar ${ }^{36}$. Hoewel die bogenoemde karakteristiek nog nie alles na vore bring wat oor die presbiteriaal-sinodale kerkordelike struktuur gesê kan word nie, vat dit tog die mees essensiële punte saam.

\section{Historiese opmerkings}

Die presbiteriaal-sinodale kerkordelike struktuur is die een struktuur wat trag om reg te laat geskied aan die kerk as 'n pneumatiese organisme, waarin die verbondenheid van Jesus Christus met die ware gelowiges wat $\mathrm{Hy}$ om Hom versamel het, die beste tot sy reg kan kom. As die Nuwe Testament egter sorgvuldig nagelees word, is dit ook duidelik dat dit nie die enigste kerklik-organisatoriese struktuur is wat uit die Heilige Skrif gelees kan word nie. Die vadere het in hierdie verband bepaalde keuses gemaak en so het ons, as kerk, binne die kader van hierdie presbiteriaal-sinodale sisteem ontstaan en gegroei. Wanneer dié presbiteriaal-sinodale struktuur, soos dit in Nederland ontstaan en ontwikkel het, van naderby bestudeer word, is dit duidelik dat die plurale, korporatiewe staatsbeskouing en werklikhede van die 16de en $17 \mathrm{de}$ eeu 'n rol gespeel het in die kerkordelike ontwikkeling van daardie tyd. Daarom vertoon dit eiesoortige kenmerke waarin dit, in sommige besonderhede, verskil van die Franse, Skotse en Geneefse strukture, terwyl almal vanuit dieselfde Calvinistiese ekklesiologiese uitgangspunt opgebou is. Verder is dit in die Nederlandse kerkordes duidelik, as hulle vergelyk word met die ekklesiologie van Calvyn, dat daar al 'n aksentsverskuiwing van die pneumaties-Christokratiese na die statutêr-juridiese interpretasie en verstaan van die kerklike struktuur is. Dit is nauurlik ' $n$ gevaar wat altyd bestaan omdat die gelowige nié 'n sondelose is nie. Daarom gebeur dit dat die kerklike organisasie of ordening nie meer 
verstaan word as 'n middel tot 'n doel nie, naamlik die verkondiging van die evangelie en die uitbreiding van die koninkryk nie, maar as 'n doel in homself ${ }^{37}$. Dié aksentsverskuiwing hoef nie 'n struktuurverandering te veroorsaak nie, maar vind plaas wanneer daar 'n verskuiwing in en van teologiese waardes in die kerk na vore kom. 'n Mooi voorbeeld hiervan is die Gereformeerde Kerken in Nederland wat vandag nog funksioneer met die feitlik gekanoniseerde Kerkorde van Dordrecht van 1619. Tog word kettery vandag deur professore en predikante van die Gereformeerde Kerken in daardie kerkverband aanvaar èn verdra, nieteenstaande die feit dat die struktuur van die Dordtse Kerkorde kettery as 'n sonde-by-uitstek kwalifiseer. Dié fout lê nie by die kerkorde nie, maar by die skynbare onvermoë van die betrokke kerklike ampte en vergaderings om kettery, dit wil sê 'n volhardende afwyking van die leer van die kerk soos in die belydenisskrifte uiteengesit, raak te sien èn dan op te tree $^{38}$.

Só word die doel van die kerklike struktuur, wat ontwerp is om die volk van God of die geroepe gelowiges so te orden "... dat die ware godsdiens onderhou word en die ware leer oral versprei word, die oortreders op geestelike wyse vermaan en in toom gehou kan word en, dat ook die armes en bedroefdes volgens hulle nood gehelp en getroos kan word" ${ }^{\prime 39}$, verydel en vernietig.

As dié saak histories besien word, is dit duidelik dat die Calvinistiese presbiteriaal-sinodale kerklike organisasie deur die eeue heen in verskillende rigtings uitgelê en vervorm is, onder andere in die tyd van die rasionalistiese Verligting, deur die kollegialisme, deur die opvattings van die parlementarisme èn die demokrasie. Dit is verstaanbaar, want dit is makliker en meer byderwets om die amp in sekulêre sin uit te lê as volgens die Nuwe-Testamentiese voorskrifte, veral as die Nuwe Testament nie meer as Woord van God verstaan word nie maar, byvoorbeeld, as 'n vervalsing van die oorspronklike Jesus-boodskap ${ }^{40}$. Net so word die verstaan van die presbiteriaalsinodale struktuur problematies as die belydenisskrifte afgewys word omdat dit nie op 'n "wetenskaplike" eksegese gebou is nie, soos in die 19de eeu betoog is". Gewoonlik, so leer die Kerkgeskiedenis, is die beroep op "wetenskaplikheid" slegs 'n poging om 'n innerlike opstand teen en verwerping van die duidelike Woord van God te verberg.

In ons eie kerkregtelike verlede is ons nogal belas deur die verminking van die grondbeginsels van die presbiteriaal-sinodale kerkordelike struktuur, enersyds deur die patronaatsreg wat die VOIC met ' $n$ harde hand gehandhaaf het en andersyds deur die feit dat in Nederland in 1816 en daarna 'n kerklike reglement-reeks ingevoer is wat meer deur die denkbeelde van die Verligting gedra is as deur 'n poging om na die aanwysings van die Skrif te handel. So is 'n 
sekulariserende èn demokratiserende tendens in ons kerkordelike struktuur ingedra en bestendig. Die 1816-kerkordenende denke is nogal sterk beïnvloed deur die koddige 19de-eeuse opvatting dat die sigbare kerk, wat op dieselfde vlak as enige andervrywillige vereniging in die staats- en gemeenskapsbestel waardeer is, géén verband het of hoef te hê met die "onsigbare kerk" ofte wel die versameling van geroepe heiliges nie. Dit het meegebring dat die gewone verenigingsreg gesien is as die basiese patroon waarop die kerklike struktuur gebou moet word. So word in daardie denke, waar die pragmatiese uit die aard van die saak hoogty kan vier, die opvattings oor die kerk as geheel, die plaaslike gemeente, die amp en die vergaderings van die ampte grotendeels gesekulariseer. Hier is daar geen sprake meer daarvan dat die kerklike struktuur of organisasie 'n poging moet wees om die Christokrasie te verwerklik nie. Al wat belangrik was, was om die opvattings van die demokrasie en die regte en vryhede van die individu in die kerklike organisasie te verwoord. Daarom is in die Nederlandse kerk ook elke vorm van leertug afgeskaf omdat die (sigbare) kerk hom onder geen omstandighede wou blootstel aan die beskuldiging dat die gewetens gebind of die vryheid van die enkeling-mens aan bande gelê word nie ${ }^{42}$. Dit het meegebring dat die Nederlandse Hervormde Kerk steeds meer en meer agteruitgegaan het en al meer invloed en seggenskap verloor het soos dié kerk toenemend in die wêreld getuig het oor baie dinge, behalwe oor die evangelie van Jesus Christus, soos dit in die Heilige Skrif, opgeteken is.

Hoewel dit waar is dat die kerklike struktuur, die organisatoriese inrigting van die kerk nié van primêre wesenlike belang is vir die regte verkondiging van die evangelie in opdrag van Christus nie, is dit óók waar dat ' $n$ kerklike struktuur wel deeglik 'n ernstige belemmering vir die verkondiging van die suiwere evangelie is en kán wees, soos onder andere die Roomse Kerk voortdurend bewys ${ }^{43}$.

Die sekulariserende en demokratiserende tendens is ook in ons kerklike ordening ingedra met die 1824-Kerkwet van die Kaapse kerk as die invalspoort. Hoewel daardie 1824-Kerkwet nie in alle besonderhede die Nederlandse voorbeeld van 1816 navolg nie, het dit tog belangrike aksente in die presbiteriaal-sinodale kerkordelike struktuur verskuif $f^{\text {H. }}$. Ons eie Kerkwet van 1862 wat in 1869 hersien is, het ook onder die invloed van die destydse Nederlandse kerklike reglemente gestaan nadat die pad daarvoor oopgemaak is deur die 1824-Kaapse Kerkwet ${ }^{45}$. Die enigste poging wat aangewend is om die 1869-wet grondig te hersien, is in 1888 aangepak. Vanweë die kerklike situasie van daardie tyd is die hersiening egter nooit verwerklik nie ${ }^{46}$. So het die Wet van 1869 , met min ingrypende wysigings, ons kerklike struktuur bly bepaal tot in 1950. Dit beteken dat die 1869-Wet 'n belangrike rol gespeel het in die vaslegging van 'n 
bepaalde kerkordenende tradisie wat nié primêr uit die voedingsbodem van die presbiteriaal-sinodale kerkordenende denke voortgekom het nie. Dit bly natuurlik ook waar dat bepaalde momente uit die presbiteriaal-sinodale denke bly voortleef het in ons kerklike struktuur, ondanks die ontwikkelinge op hierdie vlak, van 1824 tot 1950.

\section{Opmerkings oor die 1869-Kerkwet}

Dit is miskien nodig om net 'n paar opmerkings te maak oor die 1869-Kerkwet en waar dit verskil van die oorspronklike Bybels-reformatoriese presbiteriaal-sinodale struktuur. Uit die aard van die saak kan hier nie uitvoerig op dié saak ingegaan word nie omdat dit te ver sou voer. Tog kan die volgende argumente, onder andere, na vore gebring word.

1. In die $1869-$ Wet is dit duidelik dat die kerk primêr as 'n vrywillige vereniging in die staatsgemeenskap gesien word. Die belydende karakter van die presbiteriaal-sinodale kerkordes ontbreek en die hele klem lê op die administratiewe, die besturende en handhawende karakter van die kerklike orde. Juis in die algemene toon van die Kerkwet word die sekulariserende tendens, wat ook aangetref word in die Kaapse Kerkwet van 1842 en die Nederlandse reglemente van 1816 èn daarna, na vore gebring.

2. Die vergadering van die ampte word hiér kerklike besture en daar vind 'n gesagsverskuiwing plaas en wel in dié sin dat nie meer Jesus Christus nie en ook die geroepe en bevestigde ampsdraer nie meer diegene is wat primêr die gesag dra nie, maar wel die kerklike vergadering. In plaas van 'n dinamies-pneumatiese gesagsopvatting word hier ' $n$ statutêr-juridiese gesag in die vergadering se hande gelê. Terselfdertyd word daar 'n hiërargie van vergaderings gebou en word die kerkraad nou gedegradeer tot die laagste vergadering en die Algemene Kerkvergadering beklee met die "hoogste wetgevende, reg sprekende en besturende magt" (hfst 1, art 3). Met hierdie formulering kom die enige hoofskap van Jesus Christus oor sy sigbare kerk in die gedrang.

Terselfdertyd word die gesag van die Algemene Kerkvergadering nóg verder beklemtoon deurdat daar ' $n$ kontinuerings- of wel uitvoerende Kommissie in die lewe geroep word om die besluite wat geneem is uit te voer of te laat uitvoer, en "in het algemeen alle zaken waarnemen, die met den bloei en de handhaving der tucht in de Ned. herv. kerk in verband staan" (hfst 2, art 2). Dié kommissie wat in sekere sin as 'n synodus contracta funksioneer, is dan die sluitsteen van ' $n$ piramidale gesagstruktuur van vergaderings. 
Die hele anti-hiërargiese opvatting ten opsigte van die ampte en die ampsdraers onderling word deur hierdie strukturering deurkruis. Terselfdertyd word aan die predikant ook 'n duidelike voorrangsposie ten opsigte van die kerkraad en die ander twee ampte gegee (hfst 4 , art 4,5,6,7) terwyl die rotasiebeginsel ten opsigte van afgevaardigdes na meerdere vergaderings nie ter sprake kom nie. Dit hang in sekere sin saam met die feit dat voor 1900 daar nie ' $n$ ringsvergadering bestaan het nie. Selfs wanneer die ringsvergadering na die Engelse Oorlog ingestel word, is daar geen direkte organisatoriese verband tussen die kerkraads-, rings- en Algemene Kerkvergadering nie. Dié situasie duur tot vandag toe voort en die ringsvergadering is in ons kerklike struktuur nog steeds 'n soort fremdkörper.

3. 'n Positiewe faset van hierdie kerklike struktuur is dat die handhawing van die leertug spesifiek genoem word (hfst 13, art 19) èn dat die proponentsondertekeningsformule baie duidelik die erkenning van die belydenisskrifte as norm en reël van die prediking vereis. Dit is ook opvallend dat ons in ons Kerk die leertug nog altyd baie nougeset gehandhaaf is, soos uit die gevalle van ds AJ Begemann en ds CJH Ruysch van Dugteren blyk ${ }^{48}$.

Hoewel die kerklike struktuur dus 'n heeltemal ander aansig vertoon as wat die kerk in die belydenisskrifte het, is dit tog duidelik dat die eis wat aan die kerklike struktuur gestel word deur die belydenisskrifte, nié wesenlik deur die struktuur verander is nie. Die relatiewe waarde van die struktuur word hiermee onderstreep solank die geloof en die verkondiging van die kerk volgens die Skrifte is.

Tog was dit duidelik dat hierdie kerklike struktuur onbehaaglik vir die kerk as geheel was. Kort na die laaste Wêreldoorlog van 1939-1945 is in Nederland die kerklike struktuur weer heeltemal verander en dit vanweë die feit dat die teologiese insigte van $\mathrm{Ph} J$ Hoedemaker, Th L Haitjema, AA van Ruler, O Noordmans, AFN Lekkerkerker en hulle medestanders getriomfeer het. Dit het meegebring dat 'n nuwe kerkorde daar in 1950 aanvaar is ${ }^{49}$. Dit het in ons kerklike kring meegebring dat ook 'n nuwe kerkwet aanvaar moes word, nou geskoei op die lees van die 1950-Kerkorde van die Nederlandse Hervormde Kerk. So het die Algemene Kerkvergadering van 1951 'n nuwe Kerkwet aanvaar, sonder dat dié verandering voorafgegaan is èn voortgevloei het uit ' $n$ indringende studie en bespreking van die Kerk en sy organisatoriese struktuur nie. Daarom het die 1951-Kerkwet ook nog belangrike leemtes bly vertoon. 


\section{Opmerkings oor die Kerkwet van 1951}

Die Kerkwet van 1951, sorgvuldig voorberei deur die Raad vir Regsadvies, het nogal noukeurig op die voetspoor van die 1950-Kerkorde van die Nederlandse Hervormde Kerk geloop. Prof SP Engelbrecht het van die nuwe Kerkwet gesê $\hat{e}^{50}$ :

"Die kou-juridiese het weggeval en uit die geheel spreek 'n meer belydende karakter. Die kerk bepaal nie meer in die eerste plek nie, maar bely en uit hierdie belye volg die riglyne en die bepalings."

Oor die algemeen vertoon die Kerkwet van 1951 'n terugkeer na 'n hele paar van die basiese reformatoriese presbiteriaal-sinodale beginsels. So word die belydenisskrif se plek en funksie in die kerklike lewe sorgvuldig omlyn (art XI) en word in dieselfde artikel ook pertinent gestel:

"Die kerk bely ... telkens opnuut Christus as die Hoof van die kerk en as Heer van die wêreld."

Daarby word die apostolaat van die kerk sterk beklemtoon en word dit as beginsel gestel dat die kerklike struktuur ' $n$ middel tot ' $n$ doel is, naamlik "die voortdurende arbeid aan die kerstening en reformasie van die volk en deur die evangelisering van Jood en heiden, sodat alle volke die verlossing wat in Jesus Christus is, kan verkry met die ewige heerlikheid (art X).

Die amp word meer as ' $n$ dienswerk waardeer en die berdemde anti-hiërargiese klousule van die Emdense sinode van 1571 word in art VI heringevoer. Maar jammer genoeg, is die hiërargie van vergaderings èn die funksionering van die gesag in en van die kerk nie ook verander nie. Hier het die statutêr-juridiese opvatting, waarskynlik vanweë administratiewe pragmatisme, tog wéér oor die Christokraties-pneumatiese oorwegings geseëvier. Nie alleen is die kontinueringsvergaderings van die meerdere vergaderings gehandhaaf nie, maar mettergaan is dit ook uitgebrei en het die bestuursopvatting ten opsigte van die vergaderings van die ampte steeds sterker geword. Daarmee word in feite èn deur die afwesigheid van die rotasiebeginsel by die benoeming van afgevaardigdes na die meerdere vergaderings die anti-hiërargiese klousule van art VI weer kragteloos gemaak. In hierdie verband kan mens miskien let op die opmerking van Osterhaven ${ }^{51}$ :

"Human pride and proneness to error, the tendency to absolutize one's own position, and the failure to recognize one's own shortcomings are constant threats to spiritual vitality. The temptation for the church to become a religious establishment 
whose leaders become priests interested in personal position and the perpetuation of certain forms of religion instead of prophets dedicated to proclaim the Word that the Spirit gives them, is perennial, especially where the institutional life of the church is highly developed. Establishment, institutionalism, bureaucracy are pervision of ecclesiastical life that plague every denomination."

As gelet word op die kerkordelike reëlings ten opsigte van die amp en sy dienswerk in die kerk en op die reëlings ten opsigte van die vergaderings van die ampte is dit duidelik dat ons in dié opsig nog meer in terme van die gesekulariseerde 19de-eeuse kerklike reg dink as volgens die riglyne van Skrif en belydenis. Dit is natuurlik waar dat die statutêr-juridiese opvatting ten opsigte van die taak en funksie van die vergaderings van die ampte baie gerieflik is. Dit bring mee dat die predikant, by voorbeeld, niks méér hoef te doen as om self weg te kruip agter een of ander uitspraak van 'n vergadering en so die verantwoordelikheid om self op grond van die Skrif en gelei deur die Gees van God 'n besluit te neem, kan ontduik ${ }^{52}$. Dit gebeur juis omdat die verantwoordelikheid om ' $n$ besluit te neem en dit uit te voer in die hande van die vergadering geplaas word. Sodoende word die predikant of ouderling of diaken onthef van die verantwoordelikheid om die besluit wat geneem is, sèlf uit te voer. Dit is juis waar ons dan by die punt kom waar ons eindeloos vergaderings hou en tog niks doen nie.

Hierdie situasie hèt al ' $n$ reeks misstande in ons kerklike lewe veroorsaak en dit is nogal merkwaardig om te sien hoe die vergaderings van ampte dié misstande voortdurend met ' $n$ blinde oog besien. Tog bly dit ' $n$ oop vraag of dit moontlik is om selfs in die kerk 'n gesindheidsverandering teweeg te bring deur' $n$ verstelling in die kerklike struktuur te maak. As die predikante nie meer weet wát die Woord van God is nie, as die predikante nie meer in staat is om die evangelie van Jesus Christus in die Bybel raak te lees nie, is dit seker ook onmoontlik om te verwag dat die volk van God die evangelie van die kansel sal hoor ${ }^{53}$. Laat my toe om weer 'n Engelse aanhaling te maak en te verwys na' $n$ opmerking van TF Torrance ${ }^{54}$ :

"It is high time we asked again whether the Word of God really does have free course amongst us and whether it is not after all bound and fettered by the traditions of men. The tragedy, apparently, is that the very structures of our Churches represent the fossilization of traditions that have grown up by practice and procedure, have become so hardened in self-justification that even the Word of God can hardly crack them open. There is scarcely a Church that claims to be ecclesia reformata that can truthfully claim to be semper reformanda." 
Tog is dit ook waar dat die kerklike organisatoriese struktuur nié in staat is om die regte evangelieverkondiging ò te waarborg of te verhinder nie. Martin Luther is 'n pragtige voorbeeld van 'n gelowige dienskneg wat binne 'n dekadente kerklike sruktuur aangegryp is deur die Woord van God èn daardie Woord verkondig het ondanks die struktuur. Net so was in die 17de eeu die reformatoriese kerklike struktuur nie in staat gewees om Jacobus Arminius van sy dwaalweë te weerhou nie, hoewel sy navolgers wèl uit die kerk verban is. Dit beteken egter nie dat die kerklike struktuur nie ter sake is nie. Die ideaal in ' $n$ Bybels-reformatoriese kerk moet immers wees om 'n kerklike struktuur op te bou wat in staat is om as ' $n$ uitstekende middel te funksioneer om die evangelie van Jesus Christus, die gekruisigde en opgestane Heer van die kerk, in en na die wêreld uit te dra. Dit is miskien hier die moeite werd om weer kennis te neem van Bronkhorst se oorwoë mening ${ }^{55}$ :

"Samevattende komen wij tot de conclusie ... dat de presbyteriaal-synodale vorm van kerkorganisatie geacht mag worden die vorm van "vertaling" van het apostolaat te zijn, waarin de Christusheerschappij door Geest en Woord het beste tot haar recht komt, zoodat dit stelsel zich exegetisch tegenover het geheele Bijbelse kyrugma het beste laat verantwoorden."

\section{Die ter saaklike beginsels van die reformatoriese kerkreg}

Met die gesprek oor die verkleining van die Algemene Kerkvergadering moet dit geskied, so het die Algemene Kerkvergadering besluit, "sonder aantasting van die beginsels van die reformatoriese kerkreg". Nou is dit duidelik dat in hierdie verband daar 'n paar beginsels is wat in ag geneem moet word en waarmee terdeë rekening gehou moet word. Sommige van dié beginsels sal miskien "nuut" klink omdat ons kerkregtelike ontwikkeling dié beginsels reeds in die vorige eeu laat val het en dit nié meer deel van ons kerkregtelike tradisie is nie. Dit hang natuurlik saam met die feit dat die 19deeeuse kerkreg in 'n ander rigting beweeg het as die reformatoriese kerkreg. Die geleentheid bestaan nou om weer met nuwe oë te kyk na sommige van die beginsels van die reformatoriese kerkreg en hulle aan die Skrif en die belydenis te toets. Dit mag, terloops, irriterend wees vir sommige onder ons dat die belydenisskrifte hier 'n rol moet speel. Maar aan die ander kant het elke predikant die geldigheid en die normerende kwaliteit van die belydenisskrifte met sy handtekening erken ${ }^{56}$. Solank daar dus nie veranderinge in die belydenisskrifte aangebring is nie kan op die vakgebied van die kerkreg nié met ' $n$ ander kerkbegrip gewerk word as dié een wat in die belydenisskrifte voorkom nie. Die uitgangspunt bly dus die Skrif 
en die skriftuurlike ekklesiologie soos dit wat sy grondlyne betref, neergelê is in die belydenisskrifte.

Van hieruit kan daar, by wyse van stellings, die beginsels van die reformatoriese kerkreg wat hier ter sake is, 'n oomblik na vore gebring word.

1. Jesus Christus is die enige, gesaghebbende Hoof en Heer van sy kerk. Hy is die enigste gesagsdraer in sy kerk en dit beteken dat sy Woord, die Heilige Skrif, die grense van die kerk èn die grense van alle gesag, ook die afgeleide gesag, in die kerk verteenwordig. Dit gaan dus in die kerklike struktuur om hierdie hoofskap en gesag van Jesus Christus tot uitdrukking te bring, om die kerklike organisasie só te struktureer dat dit vir almal duidelik is dat nie mense nie, maar Jesus Christus alléén sy kerk deur middel van die Woord en die Heilige Gees versamel, versorg, opbou en lei.

2. Die grondslag van die presbiteriaal-sinodale stelsel is die gemeente, want daar word God se Woord reg verkondig, daar word die sakramente volgens hulle instelling bedien en daar word die tug gehandhaaf sodat almal in gehoorsaamheid aan Jesus Christus gehou word. Dit is opvallend in die Nederlandse Geloofsbelydenis dat daar primêr die gemeente na vore kom wanneer oor die kerk gepraat word ${ }^{\mathbf{5 2}}$. Tog is dit juis so dat die presbiteriaal-sinodale sisteem nie alleen die kerk selfstandig ten opsigte van die owerheid en staat wil organiseer nie maar óók die onderlinge verhouding van die gemeentes tot mekaar wil reël. Die reformatoriese gemeentes was dus nooit selfstandig of outonome "kerke", soos die Doleansie-Kerkreg van Kuyper in die 19de eeu dit stel nie $^{58}$. Die reformatoriese gemeentes het wèl geweet dat waar die gemeente is, daar is die kerk, maar terselfdertyd word die bestaan van meerdere dergelike gemeentes en 'n landswye of wêreldwye "liggaam van die kerk" (NGB, art 32) duidelik erken ${ }^{59}$. Dáárom stel art II van ons Kerkwet, na art I: "'n Gemeente is die verskyningsvorm van die kerk op elke aangewese plek."

Dit is egter duidelik dat soos òns kerkordelike struktuur táns funksioneer, die beginsel nié tot uitdrukking kom nie. In plaas daarvan dat die gemeente as die grondslag van ons stelsel funksioneer, word die gemeente slegs waardeer as die onderste laag van 'n piramidale struktuur wat slegs daar is om die "topstruktuur" wat eintlik die kerk is, te dra en te versorg ${ }^{60}$. Miskien moet ons wéér 'n keer daaroor besin of die totale gestruktureerdheid van die kerk nie enkel en alleen dáárop gerig moet wees dat God se Woord reg verkondig word aan die volk van God, dat die sakramente inderdaad volgens hulle instelling bedien moet word èn almal in gehoorsaamheid aan Jesus Christus gehou word. Dit is primêr die taak van die kerkraad (NGB art 30 ) en dit is en bly die doel van die kerkregering. 
Daarom kan gevra word: bestaan en funksioneer ons meerdere vergaderings van die kerk, om dit só te sê, as die "organe van bystand" van die kerkraad èn gemeente wat die mees wesenlike taak van die kerk verrig of is die meerdere vergaderings nog steeds die hoër bestuursorgane van die 19de-eeuse, rasionalistiese verenigingsreg? Hiermee hang die vraag saam of die kerkraadsvergaderings inderdaad hullesèlf verstaan in die lig van die ekklesiologie van die belydenisskrifte of het hulle óók administratiewe bestuursvergaderings geword waar die toerusting van die gelowiges feitlik nie meer ter sprake kom nie. Hier kan ons die vraag stel of die geloof, die gehoorsaamheid aan Jesus Christus ofte wel die opdrag van Efesiërs 4:11 nog as die primêre taak en doel van die amp en die primêre, verantwoordelike vergadering van die amp gesien èn aanvaar word. Die apostel Paulus waarsku die Tessalonisense: "Moenie die Heilige Gees teenstaan nie. Moenie profetiese uitsprake geringskat nie, maar toets dit en behou wat goed is. Bly weg van alles wat sleg is" (I Tess 5:19-22). Aan die Korintiërs skryf hy: "Lê julle toe op die gawes van die Gees, maar veral daarop om te profeteer" (I Kor 14:1) of soos mens óók sou kon vertaal: om God se Woord te preek of te verkondig. Maar soos die kerk al meer ontwikkel het in 'n godsdienstige "establishment" het die organisasie, die kerk sèlf, al belangriker geword en het die sigbare struktuur geleidelik die doel geword. Dit, so wil dit voorkom, is een van die basiese probleme vir die kerk wat ecclesia reformata et semper reformanda Verbo Dei wil wees en bly.

3. Die derde saak wat hier genoem kan word, is die amp as die een middel waardeur Jesus Christus sy kerk regeer. Juis rondom die regeertaak van die amp, bestaan daar by ons dikwels nie helderheid nie.

Dan is daar die hele anti-hiërargiese beskouing van die amp wat deur die Nederlandse Geloofsbelydenis, art 31 só omskryf word:

"Wat die bedienaars van die Woord betref: Hulle het, op watter plek hulle ook al mag wees, een en dieselfde mag en gesag, omdat hulle almal dienaars van Jesus Christus is - die enigste algemene Opsiener en die enigste Hoof van die Kerk."

Die beskouing raak ook die vergaderings van die ampte en die hele saak van die gesag van die vergaderings in die kerk. Die reformatoriese opvatting is dat die draer van die amp, dié een wat die dienswerk doen, as geroepe en bevestigde ampsdraer ' $n$ bepaalde gesag van Jesus Christus ontvang het. Daardie gesag word 
begrens deur die Woord en is net werklike gesag solank en vir sover die amp volgens die inhoud en reël van die Skrif uitgeoefen word. As die ampsdraers in vergadering byeen is, is die kumulatiewe gesag van die amp dit wat aan die vergadering gesag gee. Die vergadering as sodanig het geen eie gesag nie, al bestaan die neiging, volgens die institutêr-juridiese denke, om aan die vergadering sèlf ' $n$ bepaalde gesag te gee ${ }^{61}$.

4. Wat die meerdere vergaderings betref, het die reformatoriese kerkreg hulle werksterrein of opdrag, baie presies omlyn. Juis omdat die grense van die bevoegdhede van die meerdere vergaderings so sorgvuldig omlyn was, was daar géén moontlikheid dat die meerdere vergadering ' $n$ liggaam word wat al meer gesag na homself trek $n_{i}{ }^{62}$. Dit het ook meegebring dat dit net nie moontlik was dat die een vergadering sy verantwoordelikhede op 'n ander afskuif nie.

Verder was die streng deurvoering van die rotasiebeginsel, met ander woorde dat dieselfde ampsdraers nie voortdurend as afgevaardigdes na die meerdere vergadering gestuur word nie, 'n beklemtoning van die feit dat nie persone die kerk van Christus regeer nie, maar Christus sèlf. Die kontinuïteit in dié struktuur word dus nie deur mense gewaarborg nie, maar deur die Woord van God, die geloof in en gehoorsaamheid aan dié Woord en die handhawing van die kerklike orde.

Die rotasiebeginsel, wat voortvloei uit die basiese anti-hiërargiese opstelling van die struktuur, is natuurlik iets wat vreemd aan ons kerklike organisasie is. Dit wil ook voorkom asof dit in ons kerklike struktuur nie baie populêr sal wees nie omdat dit beteken dat kerklike posisies nie meer deurlopend net deur 'n paar persone beklee sal word nie. Tog is die rotasiebeginsel één van die reformatoriese kerkordelike beginsels wat aan die gedagte dat Jesus Christus die enige Hoof van sy kerk is, uitdrukking gee.

Naas die rotasiebeginsel sal ook weer met sorg gekyk moet na die plek, funksie van bevoegdhede van die kontinueringskommissies van die meerdere vergaderings. In ieder geval sou dit moontlik wees om met ' $n$ drasties verkleinde Algemene Kerkvergadering ook die frekwensie waarmee dié vergadering byeenkom, te verhoog. Indien 'n verkleinde Algemene Kerkvergadering jaarliks byeen sou kom, sal dit seer sekerlik die las wat die kommisie moet dra aansienlik kan verlig. Indien dit sou gebeur, sou ook weer gekyk kan word na die plek en funksie van die ses werkgroepe en die meer as vyftig rade, kommissies en aanstellings wat die Kommissie van die Algemene Kerkvergadering bystaan.

As die trapsgewyse verteenwoordiging van die amp op die verkleinde Algemene Kerkvergadering deur middel van rings- 
vergaderings geskied en die vergaderings ook gemotiveer kan word om los te kom van die administratief-bestuurlike, kan die betrokkenheid van alle ampsdraers by die dienswerk en lewe van die kerk waarskynlik verhoog word. ' $n$ Trapsgewyse verteenwoordiging van die amp op ' $n$ verkleinde Algemene Kerkvergadering hoef nie noodwendig te beteken dat die meerdere vergaderings die kundigheid van bepaalde ampsdraers sal moet ontbeer nie. Saam met die rotasiebeginsel en die beginsel van trapsgewyse verteenwoordiging kan dan ook die beginsel gestel word dat elke ampsdraer op 'n meerdere vergadering van die kerk spreekreg het, terwyl die stemreg beperk word tot diegene wat sittingsreg op die vergadering het.

Dit is nie nou van belang om ook nog uitvoerig in te gaan op die posisie van die professore, die predikante in buitengewone diens, die deeltydse predikante en dergelike meer nie. Dit is besonderhede wat ingewerk kan word nádat vasgestel is of die verkleining van die Algemene Kerkvergadering inderdaad volgens die beginsels van die reformatoriese kerkreg sal geskied.

\section{Slotopmerkings}

Die verkleining van die Algemene Kerkvergadering is nie maar net 'n saak van 'n paar klein administratief-juridiese verstellings nie. Die kerklike struktuur is 'n dusdanige sorgvuldig opgeboude struktuur dat ' $n$ verandering aan één faset van die orde, in feite die hele struktuur beroer. Hoewel so 'n verkleining waarskynlik nie die Wet self sal raak nie, sal dit wèl meebring dat die Bepalings, veral ten opsigte van die meerdere vergaderings, hulle samestelling, funksie en werksterrein opnuut deurdink en geformuleer moet word. Hoewel die Algemene Kerkvergadering baie stellig was dat die verkleining volgens die beginsels van die reformatoriese kerkreg moét geskied, is dit 'n oop vraag of daarmee ook 'n opdrag gegee is dat daar wéér na die werkterrein, die funksie, die gesag en so meer van die meerdere vergaderings as sodanig gekyk moet word. Daarby is dit 'n oop vraag of die beginsels van die reformatoriese kerkreg in ons kerklike leefwêreld in staat sal wees om die geykte, maar grotendeels sekulêre beginsels van die 19 de-eeuse kerkreg, wat nou al so lank in ons kerk geld, uit die pad te stoot.

Uiteindelik is die kerklike struktuur nie 'n geloofsbeginsel nie, maar middel tot 'n doel. Miskien kan mens dié doel met behulp van die Nederlandse Geloofsbelydenis, art 30 só omskrywe:

"Deur hierdie middel (= die vergaderings van die ampte) moet hulle (= die ampte) sorg dra dat die ware godsdiens onderhou word en die ware leer oral versprei word, die oortreders op 
geestelike wyse vermaan en in toom gehou kan word, en dat ook die armes en bedroefdes volgens hulle nood gehelp en getroos kan word."

Aantekeninge

* Voordrag gehou op die Predikantevergadering, Sept 1981

1. Notule van die 59 ste Algemene Kerkvergadering van die Nederduitsch Hervormde Kerk van Afrika te Pretoria op 15 Mei tot 22 Mei 1979, bl. 207 waar besluit word: "2(a) Die Kommisie van die Algemene Kerkvergadering onderneem ' $n$ studie na die beste praktiese wyse waarop die AKV verklein kan word sonder aantasting van die beginsels van die reformatoriese kerkreg. 2(b) Die resultate van hierdie studie, en 'n aanbeveling met die oog op aanname by die eersvolgende AKV, sal voor die AKV van 1983 vir kennisname aan kerkrade gestuur word."

Van belang in hierdie beslissing is dat pertinent gestel word dat die beginsels van die reformatoriese kerkreg die verkleining van die AKV moet bepaal. Daardie beginsels word onder andere uiteengesit in AD Pont, Die Historiese Agtergronde van ons Kerklike Reg, Pretoria 1981, bl 220 e.v. Vgl ook GPL van der Linde, Die Grondbeginsels van die Presbiteriale Kerkregeringstelsel, Potchefstroom 1965.

2. As gelet word op die inhoud van die artikels wat in die Hervormde Teologiese studies gepubliseer word, is dit opvallend hoe min daar oor die vakgebied van die Kerkreg of die strukturering van die kerk geskryf word.

3. Dit is 'n tipe Pauliniese omskrywing wat gevind word onder andere in Efesiërs 1:14; Tit 2:14.

4 Vgl I Kor 12:14 e.v.

5 Uit die NT is dit duidelik dat die ekstensief-apostolêre en die intensiefbevestigende elemente van die volk van God nie in spanning tot mekaar staan nie maar slegs twee kante van dieselfde saak is.

6. Paulus stel die noodsaaklikheid van 'n vaste orde in die gemeente baie sterk, vgl Kol 2:5 en hy wil hê dat die gemeente dié orde gehoorsaam moet wees, I Kor 16:16; Ef 5:21, vgl ook I Kor 14. In sommige gevalle gee Paulus selfs bevele aan die gemeente, I Tess. 4:2; I Tim 1:18 ea. So word soms na I Tim 2:1-3, 13 verwys as die oudste kerkorde. Feit bly dat die ordening en geordende bestaan van die volk van God nie as 'n willekeurige aangeleentheid beskou word nie.

7. Vgl oa die Discipline Ecclésiastique, 1559, van die Franse kerk.

8. Vgl oa AD Pont, aw, bl 6 e.v.

9. In daardie denke is die godsdienstige enkeling en die persoonlike, pneumatiese betrekking tussen Christus en die afsonderlike gelowige die bepalende motief en word die korporatiewe begrippe soos volk van God of liggaam van Christus heeltemal op die agtergrong gestoot.

10. Rud Sohm, Kirchenrecht Bd 1, Leipzig 1892, Vorrede, Sx.

11. Vgl oa H Ridderbos, Paulus. Ontwerp van zijn Theologie, Kampen 1966, bl 492.

12. Joh. Heckel, Das blinde undeutliche Wort "Kirche", artikel in Ges Aufsätze, Köln Graz 1964, S 659: Ein hauptproblem, Ja das kemproblem des Kirchenrecht der christlichen Kirche ist die Frage nach dem ius divinum. Wie immer sie zu beantworten sein mag, so viel ist gewiss: Von der Antwort wird die Stellung der Kirche zum Recht, insbesonders ihre Auffassung des Kirchenrechts sowie ihr rechtliches Handeln entscheidend bestimmt.

13. In hierdie verband kan verwys word na $W$. van 't Spijker, Goddelijk recht en kerkelijke orde bij Martin Bucer, Kampen 1972 en na al die verwysings wat dáárin na vore kom. Vgl ook J Bohatec, Calvin und das Recht, Graz 1934, asook Jürgen Baur, Gott und Recht im Werke Calvins, Bonn 1965.

14. $\mathrm{Vgl}$ in hierdie verband $\mathrm{H}$ Noltensmeier, Reformatorische Einheit. Das Schriftverständnis bei Luther und Calvin, Graz-Köln 1953, S44 f.

15. W van 't Spijker, aw, bl 11.

16. Vgl AD Pont, aw, bl 21 e.v.

17. Vgl in hierdie verband die Tweede Switserse Geloofsbelydenis, 1566, 1:4. 
18. Die Franse Geloofsbelydenis van 1559, art 25 stel: Nou dat ons Jesus Christus alleen deur die evangelie in vreugde kan ontvang (Rom 1:16 e.v. en Rom 10:17 e.v.), glo ons dat die orde van die kerk wat deur sy gesag daargestel is, heilig en onaantasbaar moet wees...

19. Dit is opvallend dat net één Calvinistiese sinode dit wou stel, naamlik die Westminster Assembly van 1646 wat in sy uiteensetting The Form of Presbyterial Church Government and of; Ordination of Ministers in besonderhede die Skriftuurlike basis vir die presbiteriale kerklike orde aantoon. George Gillespie, een van die Skotse lede van dié Assembly, het in 1646 sy Aaron's Rod Blossoming, or the Divine Ordinance of Church Government Vindicated gepubliseer waarin hy die presbiteriaal-sinodale kerklike orde punt vir punt skriftuurlik probeer regverdig teenoor 'n episkopaalse of independentistiese orde.

20. Hoe dit verstaan moet word, word duidelik gemaak deur die Nederlandse Geloofsbelydenis, art 32: Ons glo intussen dat die regeerders van die kerk, al is dit nuttig en goed om onder mekaar 'n bepaalde orde tot instandhouding van die liggaam van die kerk in te stel en te handhaaf, tog noukeurig moet oppas om nie af te wyk van wat Christus, ons enigste Meester, vir ons ingestel het nie ... Ons neem derhalwe slegs dit aan wat kan dien om eendrag en eenheid te bevorder en te bewaar, en ons onderhou alles in gehoorsaamheid aan God.

21. Vgl B Spoelstra, Calvyn se kerkreg en invloed op kerke in Suid-Africa, referaat gelewer by die Calvynkongres, Pretoria 1980, bl 7.

22. Joh Calvinus, Institutio christianae religionis, 1559,IV 6.9 ea.

23. Vgl Nederlandse Geloofsbelydenis, art 27 en ook 29.

24. Vgl in hierdie verband JJ van der Walt, Christus as Hoof van die kerk en die Presbiteriale Kerkregering, Potchefstroom 1976, asook AD Pont, aw, bl 190-195.

25. Vgl Die Heidelbergse Kategismus, Vraag en Antwoord 54, en ook die Nederlandse Geloofsbelydenis art 27.

26. Vgl die Geneefse Kategismus, Vraag en Antwoord 96 en 99.

27. Vgl Die Heidelbergse Kategismus, Vraag en Antwoord 53 en ook 54.

28. Vgl die Franse Geloofsbelydenis art 21 en Die Heidelbergse Kategismus, Sondagsafdelings 32-52.

29. Vgl die Skotse Geloofsbelydenis 1560, art 18: The interpretation quhairoff (= die Woord van God), we confesse, neither appertaines to private nor publick persone, nether zit to ony Kirk, for ony preheminance or prerogative, personallie or locallie, quhilk ane hes above ane uther, bot appertaines to the Spirite of God, be the quhilk also the Scripture was written. When controversie then happines, for the right understanding of ony place or sentance of Scripture, or for the reformation of ony abuse within the Kirk of God, we ought not sa meikle to luke what men before us have said or done, as unto that quhilk the haly Gaist uniformelie speakes within the body of the Scriptures, and unto that quhilk Christ Jesus himselfe did, and commanded to be done. For this is ane thing universallie granted, that the Spirit of God, quhilk is the Spirite of unitie, is in nathing contrarious unto himselfe. Gif then the interpretation, determination, or sentence of ony Doctor, Kirk or Counsell, repugne to the plaine Word of God, written in ony uther place of the Scripture, it is a thing maist certaine, that there is not the true understanding and meaning of the haly Ghaist, although that Councels, Realins, and Nations have approved and received the same.

30. Vgl die Franse Geloofsbelydenis art 27 e.v., die Skotse Geloofsbelydenis 1560, art 18 en die Nederlandse Geloofsbelydenis, art 29. Die Tweede Switserse Geloofsbelydenis, art 17, noem net die eerste twee nota ecclesiae, maar sien die handhawing van die tug as 'n noodwendige vrug van die gehoorsaamheid aan die Woord - vgl die Heidelbergse Kategismus, Vraag en Antwoord 64 èn 86 . Die beklemtoning van die derde nota ecclesiae beteken dat die moment van die vergewing van die sonde 'n deurlopende rol in die kerklike lewe moet speel omdat die gelowige altyd simul iustus ac peccator (Luther) bly - vgl die Heidelbergse Kategismus, Vraag en Antwoord 114.

31. Die Franse Geloofsbelydenis, art 27: Nogtans glo ons dat dit belangrik is om met sorg en aandag vas te stel wat die ware kerk is, want die benaming is al dikwels misbruik. Ons sê dan, volgens die Woord van God, dat dit die versameling van die gelowiges is wat ooreengekom het (qui s'accordent) om sy Woord te volg èn 
die ware godsdiens wat daardeur geleer word, wat gedurende hulle lewe daarin vooruitgaan en al meer toeneem in hulle vrees vir die Here ... Vgl ook in hierdie verband B Spoelstra, Calvyn en die grense van die kerk, artikel in In die Skriflig, 1978, nr. 45, bl 20 e.v.

32. Vgl Die Tweede Switserse Geloofsbelydenis, art 17 en 18.

33. Nederlandse Geloofsbelydenis, art 30.

34. Die H Skrif verwys met verskillende begrippe na die lede van die Christelike geloofsgemeenskap, naamlik:

(a) die wat geroep is - I Kor 1:2; Ef 2:19;

die uitverkore volk - Kol 3:12; II Joh 1:13;

die betroubares - II Tim 2:2; Op 2:13; Kol 1:1

die heiliges - I Kor 1:2; Fil 1:1;

die broeders - I Tess 1:4; Hand 15:23; en 40;

(b) die gelowiges - Hand 4:4 en 32; Rom 10:13-14;

(c) die wat Christus bely - Rom 10:9; Mt 10:32;

(d) die wat aan Christus en sy Woord gehoorsaam is - Hand 5:29 ea.

Oor die algemeen word aanvaar dat ' $n$ belydenis van geloof in Jesus Christus die primêre voorwaarde vir lidmaatskap van die kerk-gemeente is. Tog word die gedoopte kinders van die verbondsouers óók beskou as lede van die kerk-gemeente, hoewel die reg om deel te hê in die formele ordening van die kerk beperk word tot diegene wat reeds belydenis van geloof afgelê het.

35. Prof $\mathrm{HH}$ Esser, in 'n ongepubliseerde referaat by U.P. 1981. The Authority of the Church and Authority in the Church according to the Reformed Tradition. Daar maak hy ook die interessante opmerking: The New Testament presents three arrangements of orderly church leadership: the collegial charismatic order, without a fixed structure of ministries (cf, the Johannine letters); the presbyterial structure of church leadership (cf. I Cor 12; Rom 12; Letter to the Philippians); and the episcopal order, (Pastoral Letters, esp. I Tim).

36. Vgl in hierdie verband oa PY de Jong, The Genius of the Reformed Church Policy, artikel in Church Order and Church Union, Glenside 1967, p 17-21.

37. Tov die doel van die kerk vgl Joh Calvinus, $l c$, IV 12. 5, 7 en 11 asook die Nederlandse Geloofsbelydenis, art 29.

38. Vgl ook die opmerkings van B Spoelstra, aw bl 28-29.

39. Nederlandse Geloofsbelydenis, art 30.

40. Vgl oa SGF Brandon, Jesus and the Zealots, Manchester 1967.

41. $K$ Barth se opmerkings in hierdie verband bly nog steeds ter sake, vgl sy Gotteserkenntnis und Gottesdienst nach reformatorischer Lehre, Zollikon 1938, $\mathrm{S} 42 \mathrm{f}$.

42. Vgl AJ Rasker, De Nederlandse Hervormde Kerk vanaf 1795, Kampen 1974, bl 41 e.v.

43. Interessant is in hierdie verband die onderskeiding tussen die ware en valse kerk, soos dit in art 29 van die Nederlandse Geloofsbelydenis voorkom. Daar word van die ware kerk gesê: Kortom, dat almal hulle ooreenkomstig die suiwere Woord van God gedra, alles wat daarmee in styd is, verwerp en Jesus Christus as die enigste Hoof erken. Wat die valse kerk betref, word gesê ... dit skryf aan homself en sy besluite meer mag en gesag toe as aan die Woord van God; dit wil homself nie aan die juk van Christus onderwerp nie ... dit vertrou meer op mense as op Christus ... ens.

44. $\mathrm{Vgl}$ in hierdie verband oa EPJ Kleynhans, Die Kerkregtelike Ontwikkeling van die Nederduitse Gereformeerde Kerk in Suid-Afrika 1795-1962, DD-proefskrif US 1973, bl 119 e.v.

45. Vgl in hierdie verband SP Engelbrecht, Geskiedenis van die Nederduitsch Hervormde Kerk van Afrika, Pretoria 1953, bl 137 e.v.

46. Die veranderinge wat in 1888 op die Algemene Kerkvergadering aanvaar is, is nie deurgevoer nie omdat ds MJ Goddefroy regsadvies ontvang het om nie die Kerkwet te verander nie sodat die kontinuïteit met die kerk van voor 1885 daardeur beklemtoon kon word. Terselfdertyd moes die hofsake oor die besitreg van die kerkgeboue te Trichardtsfontein en elders op grond van die 1869-Wet gevoer word.

47. Hier word gebruik gemaak van die uitgawe van 1880 wat by die drukker JP Borrius te Potchefstroom uitgegee is.

48. Vgl SP Engelbrecht, $a w, \mathrm{bl} 261$ en 368 . Van besondere belang in hierdie verband is 
die uiteensetting van MJ Goddefroy, Neen, niet Roomsch, Pretoria 1911 waar hy uitvoerig die funksie van die belydenis in ons kerklike struktuur behandel.

49. Vgl oa Th L Haitjema, Nederlandse Hervormd Kerkrecht, Nijkerk 1951, bl 92 e.v., asook AJ Bronkhorst, Schrift en Kerkorde, Den Haag 1947, bl 11 e.v.

50. SP Engelbrecht, aw, bl 383 e.v.

51. ME Osterhaven, The Spirit of the Reformed Tradition, Grand Rapids 1971, $\mathrm{p} 33$.

52. In hierdie verband is en bly dit interessant om kennis te neem van $\mathrm{H}$ von Lips, Glaube - Gemeinde - Amt, Göttingen 1979, S $106 \mathrm{ff}$ Vgl ook JL Ainslie, The Doctrines of Ministerial Order in the Reformed Churches of the 16th and 17th Centuries, Edinburgh 1940, $\mathrm{p} 62 \mathrm{f}$ en $191 \mathrm{f}$.

53. Dit is by voorbeeld interessant om te konstateer dat in Nederland daar baie predikante is wat geen ander temas meer op die kansel behandel as ontwikkelingshulp, die Derde Wêreld en apartheid nie. Van evangelieverkondiging is daar geen sprake nie en dit is dan ook nie vreemd dat die gemeente geleidelik dié "prediking" begin vermy nie.

54. TF Torrance, Iustification, artikel in Christianity Divided: Protestant and Roman Catholic Theological Issues, ed DJ Callahan et al, London 1961, p 299-300.

55. AJ Bronkhorst, aw, bl 269.

56. In Bep 73 het elke predikant met sy handtekening verklaar: Deur hierdie formule te onderteken, verklaar ek/ons dat ek/ons vas oortuigd is en glo dat die leer wat in die formuliere van eenheid uitgedruk is, in volkome ooreenstemming met die Woord van God is. Dit bly ' $n$ merkwaardige refleksie op die integriteit van diegene wat dié formule onderteken het en terselfdertyd allerlei opmerkings maak dat die formuliere van eenheid ouderwets, verouderd of nie meer geldig kan wees nie omdat dit dan slegs ' $n$ neerslag van die $16 \mathrm{de}$ - en $17 \mathrm{de}$-eeuse Teologie en Skrifverstaan sou wees. Immers deur die ondertekening van die proponentsformule het die ondertekenaar gestel: "Ek/ons ... verklaar hiermee dat ek/ons die leer wat uitgedruk is in die formuliere van eenheid ... van harte onderskryf en getrou sal verkondig ..." èn daarmee verklaar dat daardie leer volkome eietyds èn geldig is. Indien 'n predikant sou bevind dat dit nié meer so is nie, dan het hy géén ander keuse as om die pad van Bep 75 te loop nie.

57. Nederlandse Geloofsbelydenis, art 28 e.v.

58. In die Doleansie-kerkreg word die outonomie van die plaaslike gemeente geleer omdat Kuyper cs ' $n$ argument nodig gehad het vanwaar hulle regverdiging kon vind vir hulle pogings om "regmatiglik" die gemeentes aan die "sinodale juk" te onttrek. Dit is nogal interessant om daarop te let dat in navolging van die opmerkings van K. Schlaich, Kollegialtheorie. Kirche, Recht und Staat in der Aufklärung, Munchen 1969, s 166-167, die grondstruktuur van die federalistiese Doleansie kerklike orde as ' $n$ vorm van kollegialisme getipeer kan word.

59. Vgl AJ Bronkhorst, aw, bl 258-259.

60. Vgl die formulerings in Bep 14 ea plekke.

61. Dit is ' $n$ tendens wat reeds in die $16 \mathrm{de}$ - en $17 \mathrm{de}$ - eeuse Nederlandse kerkordes opgemerk kan word.

62. Vgl in hierdie verband bv Beps 14a en d; 11a, 8.1a ea. 